\title{
Land Snails (Helix aspersa) as Bioindicators of Trace Element Contamination in Campania (Italy)
}

\author{
Antonella De Roma, Benedetto Neola, Francesco Paolo Serpe, Donato Sansone, Giuseppe \\ Picazio, Pellegrino Cerino, Mauro Esposito*
}

Istituto Zooprofilattico Sperimentale del Mezzogiorno, Napoli, Italy

Email: *mauro.esposito@cert.izsmportici.it

How to cite this paper: De Roma, A., Neola, B., Serpe, F.P., Sansone, D., Picazio, G., Cerino, P. and Esposito, M. (2017) Land Snails (Helix aspersa) as Bioindicators of Trace Element Contamination in Campania (Italy). Open Access Library Journal, 4: e3339.

https://doi.org/10.4236/oalib.1103339

Received: December 28, 2016

Accepted: February 25, 2017

Published: February 28, 2017

Copyright $\odot 2017$ by authors and Open Access Library Inc.

This work is licensed under the Creative Commons Attribution International License (CC BY 4.0).

http://creativecommons.org/licenses/by/4.0/

\begin{abstract}
The occurrence of traces elements (V, Cr, Mn, Co, Ni, Cu, Zn, Cd, Hg, Sb, As, $\mathrm{Tl}, \mathrm{Pb}, \mathrm{Sn}, \mathrm{U}$ and $\mathrm{Se}$ ) in individuals of Helix aspersa from five sites of Campania region was studied. They are representative primary consumers in the terrestrial ecosystem and useful key indicator species to evaluate the environmental impact of chemicals on our lands. Each sample was analyzed by inductively coupled plasma-mass spectrometry (ICP-MS) after a microwave assisted digestion procedure. Sentinel snails allowed us to have information about the bioavailability of these elements into the environment similar in the main part of the regional land. Results indicated that elemental concentrations in all snail samples were significantly low. But within the five selected areas, the amount for each element was higher in the area of Caserta. Even though maximum admissible limits from European regulation are not even defined for these matrices, the area of Caserta represents a territory where environmental contamination may represent a high risk for human and animal health.
\end{abstract}

\section{Subject Areas \\ Environmental Chemistry}

\section{Keywords}

Snails, Sentinels, Trace Elements, Campania Region, ICP-MS

\section{Introduction}

In the last years, there has been a growing attention of the public opinion to the contamination of terrestrial environment and consequently to the quality of 
both vegetable origin products and food derived from animal bred in potentially contaminated areas.

In Southern Italy, this phenomenon regards particularly the lands of Campania Region (Area of Napoli and Caserta) after the discovery of the practice of illegal spillage of toxic waste and of uncontrolled and indiscriminate burning of waste along the roads bordering cultivated fields.

Consequently, in order to protect the consumer's health, in particular for people who live in areas close to the contaminated lands, different chemical analysis methods have been applied to provide indication concerning the environmental contaminants, such as heavy metals and metalloids [1].

Soils are the major collector for heavy metals released into the environment by anthropogenic activities. Heavy metals contamination of soil may pose risks and hazards to humans and the ecosystem through the food chain, drinking of contaminated ground water, reduction in food quality (safety and marketability), reduction in land usability for agricultural production causing doubts on food security, and land tenure problems [2] [3] [4] [5].

In the framework of ecotoxicology and ecological risk assessment, mollusks have been extensively studied as biomonitors of environmental contamination by metals. They can be considered efficient bio-indicators and bio-accumulators [6].

Some mollusks species accumulate large amounts of heavy metals and reflect the bioavailable environmental levels. For example, between mollusks, bivalve shellfish have long been used as bio-indicators of contamination in aquatic environments, rather than other groups of animals, like the case of Mytilus spp and of freshwater species Uniopictorum, Lampsilis ventricosa and Corbicula spp [7].

For the terrestrial environment, the snails, pulmonate gastropod mollusks, can be considered efficient sentinels to evaluate the presence of metals into the environment because for them there are so many factors that affect the accumulation of metals. They exhibit an extremely limited mobility or are completely sessile as adults. Due to the lack of an exoskeleton, as it is present in arthropods, mollusks are in direct contact with the ambient medium (water or soil). Therefore, these mollusks reflect the contamination of their habitat ideally. Biomonitoring attempts with snails have found an increasing interest during the last decade and a number of promising projects have already been conducted [6]. The relationships between concentrations of metals in snails and in soils have been well studied in controlled conditions as well as on the field [8]-[13].

In light of the events that have involved the lands of Campania region, concerning the environmental contamination, we decided to use snails of Helix aspersa species, already confirmed as useful metal pollution sentinels [14] [15], in order to provide consumers of fruit and vegetables of this territory, an indication of the quality and safety of soils where these foods are produced. Helix aspersa species is native to Europe but it has been introduced in several parts of the world where it has become both a pest for crops and gardens and a food item [16] [17]. 
This species is selected because it is relatively abundant and well spatially distributed over the study area. It is so common that it is one of the most proliferated terrestrial mollusks. The data collected on these primary consumers may provide an indication of the metal contamination of the soil-plant system in Campania region for a human and ecological risk assessment.

\section{Materials and Methods}

This study was carried out in the Campania Region of Italy that covers an area of about $13.600 \mathrm{~km}^{2}$. Samples were collected in the five districts of the region with particularly regards to the areas of the Napoli (NA) and Caserta (CE). These are not only the most populated and industrialized areas of the region but their lands are also the most studied because were mainly involved in the illegal waste dumping in compare to the remaining areas of Benevento (BN), Avellino (AV) and Salerno (SA). Consequently, sites of sample collection were mainly distributed in these areas, and in their neighboring lands.

Twenty adult specimens of Helix aspersa (mean weight: 10.2 g; mean shell diameter: $27.8 \mathrm{~mm}$ ) were collected during the august 2015 at each sampling site, transported in the laboratory in coolers the same day. In particular, 622 samples of snails were picked up from cultivated lands distributed on all the Campania Region territory: 171 samples come from the area of Naples, 156 from Caserta, 115 from Benevento, 111 from Avellino and 69 from Salerno (Figure 1).

Analysis of the total trace element content was carried out using 6020 method of the Environmental Protection Agency [18]. The method measures ions pro-

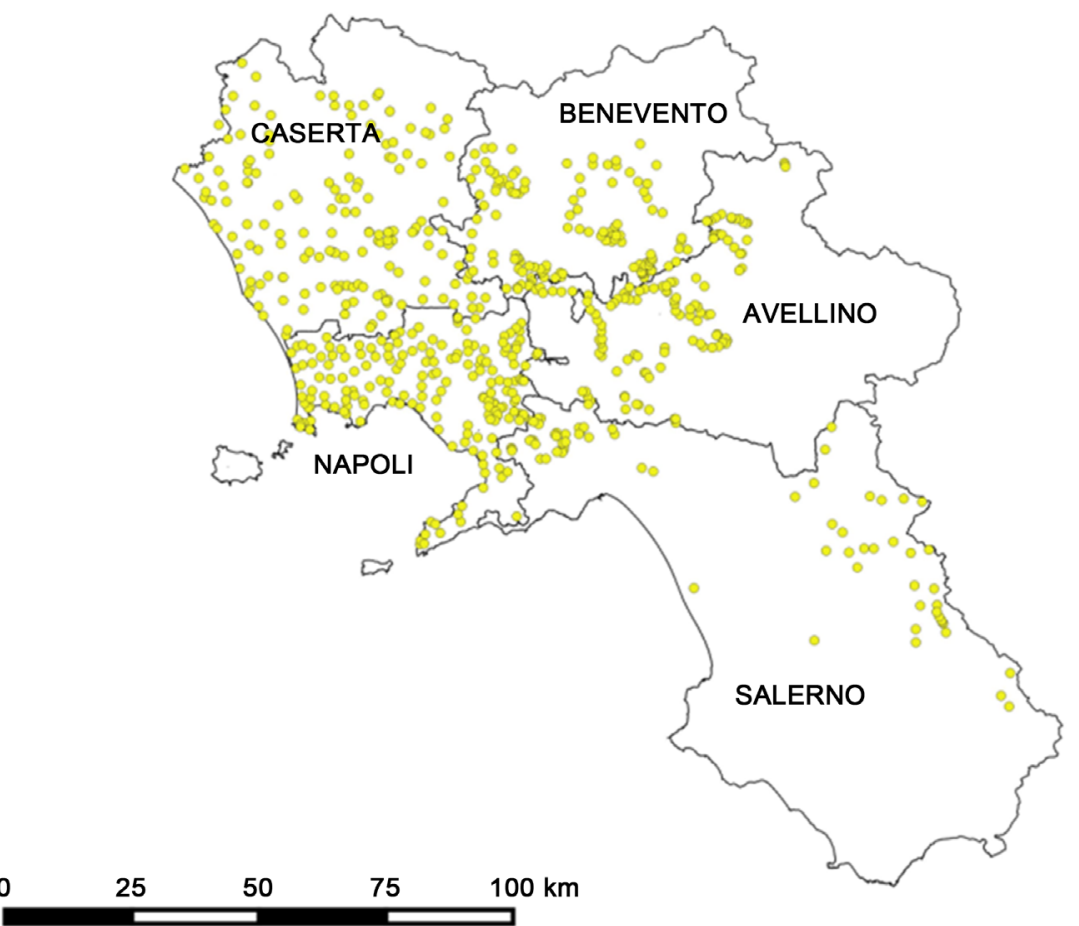

Figure 1. Geografical distribution of the Helix aspersa collection points in the five areas of Campania region. 
duced by a radio-frequency inductively coupled plasma. Analyte species originating in a liquid are nebulized and the resulting aerosol transported by argon gas into the plasma torch. The ions produced are entrained in the plasma gas and introduced, by means of an interface, into a mass spectrometer. The ions produced in the plasma are sorted according to their mass-to-charge ratios and quantified with a channel electron multiplier. After three wash with deionized water, the whole soft tissue was removed from each shell for the analysis. We selected the whole body (soft tissues and foot) because this corresponds to potential consumption by humans and to have a complete indication of the soil-plant system contamination.

Samples were homogenated and heated at $40^{\circ} \mathrm{C}$ for $24 \mathrm{~h}$. Up to $0.25 \mathrm{~g}$ of each sample was weighed into $7 \mathrm{~mL}$ PFA Teflon micro-vials (CEM. Matthews, NC, USA), $4 \mathrm{~mL}$ of ultrapure $\mathrm{HNO}_{3} 65 \%$ (Sigma-Aldrich) and $1 \mathrm{~mL}$ di $\mathrm{H}_{2} \mathrm{O}_{2} 30 \%$ (Sigma-Aldrich) were added to each vessel before re-capping. Blank samples of acid were alsocarried through the digestion procedure.Microwave vessels were loaded into a Milestone high pressure microwave (Ethos Touch model). The temperature was first ramped to $120^{\circ} \mathrm{C}$ over $3 \mathrm{~min}$, with awaitof $1 \mathrm{~min}$. And then ramped to $175^{\circ} \mathrm{C}$ over $2 \mathrm{~min}$, with a wait of $12 \mathrm{~min}$. Vessels were allowed to cool to room temperature prior to opening. Digested samples were transferred in to 7 $\mathrm{mL}$ polytetrafluoroethylenetubes and weighed. Samples were diluted with $50 \mathrm{~mL}$ of ultrapure water filtered using a 0.45 um filter and transferred into a vial for autosampler. Metal concentrations in snail soft bodies were analyzed by inductively coupled plasma-mass spectrometry (ICP-MS) (Agilent HP7500). The ICP-MS measurements were performed using the following conditions: air-carrier gas-flow rate was $0.98 \mathrm{~L} / \mathrm{min}$; auxiliary gas flow rate was $0.8 \mathrm{~L} / \mathrm{min}$; cooling gas flow rate was $16.0 \mathrm{~L} / \mathrm{min}$; RF power was $1200 \mathrm{~W}$. Precision of the analysis was calculated using three in-house replicates. Accuracy was determined using in-house reference materials.

Mean and standard errors were determined for all variables. Data are expressed by the median, minimum and maximum. Multivariate analysis was assessed between the five sites through determination of Pearson correlation coefficients and the Principal Component Analysis (PCA) using the XL-STAT 2016 software by Microsft Excel.

\section{Results and Discussions}

Samples of snails of Helix aspersa specie were collected from five areas of the territory of Campania region. They were used to define the amount of a wide range of elements such as those commonly found at the contaminated sites $(\mathrm{Pb}$, $\mathrm{Cr}, \mathrm{As}, \mathrm{Cd}, \mathrm{Hg}$ and $\mathrm{Ni}$ ), some less abundant but still toxic (V, Tl, Sb, Sn and U) and elements as $\mathrm{Cu}, \mathrm{Zn}, \mathrm{Se}, \mathrm{Mn}$ and $\mathrm{Co}$, commonly defined as plant nutrients. The determined concentrations are reported in Table 1 as median values for each element.

The elements $\mathrm{Mn}, \mathrm{Zn}, \mathrm{Ni}, \mathrm{Cu}, \mathrm{Se}$ and $\mathrm{Co}$ are considered essential for living organisms: they are important in plant nutrition as essential crop micron- 
Table 1. Median, minimum and maximum range of elemental concentrations of the snails groups from the five areas of Campania region $\left(\mathrm{mg} \cdot \mathrm{kg}^{-1}\right)$.

\begin{tabular}{|c|c|c|c|c|c|}
\hline Trace element & Caserta & Napoli & Avellino & Benevento & Salerno \\
\hline $\mathrm{Sb}$ & $0.093(0.008-4.0)$ & $0.056(0.007-5.0)$ & $0.008(0.007-0.3)$ & $0.035(0.007-1.4)$ & $0.020(0.007-1.1)$ \\
\hline As & $0.358(0.022-7.9)$ & $0.126(0.041-1.3)$ & $0.068(0.020-1.0)$ & $0.105(0.021-2.3)$ & $0.069(0.020-4.8)$ \\
\hline $\mathrm{Cd}$ & $0.781(0.099-19.0)$ & $0.682(0.200-6.4)$ & $0.923(0.184-2.6)$ & $0.496(0.051-4.3)$ & $0.627(0.229-2.1)$ \\
\hline Co & $0.472(0.064-10.6)$ & $0.152(0.068-3.6)$ & $0.197(0.071-5.2)$ & $0.266(0.078-0.7)$ & $0.177(0.067-3.7)$ \\
\hline $\mathrm{Cr}$ & $0.900(0.1-32.8)$ & $0.400(0.1-34.3)$ & $0.300(0.1-3.0)$ & $0.500(0.01-2.1)$ & $0.300(0.01-5.9)$ \\
\hline Mn & $62.5(4.5-3340)$ & $14.4(2.1-2320)$ & $34.5(10.0-499)$ & $52.1(5.1-351)$ & $23.6(4.4-1440)$ \\
\hline $\mathrm{Hg}$ & $0.011(0.009-1.6)$ & $0.012(0.007-0.2)$ & $0.009(0.009-0.1)$ & $0.010(0.008-0.1)$ & $0.009(0.009-0.1)$ \\
\hline $\mathrm{Ni}$ & $1.440(0.362-18.4)$ & $0.814(0.310-11.8)$ & $0.677(0.335-8.4)$ & $0.685(0.324-3.2)$ & $0.800(0.302-18.2)$ \\
\hline $\mathrm{Cu}$ & $35.9(0.9-1740)$ & $87.8(10.8-3340)$ & $20.9(6.4-166)$ & $37.3(10.1-899)$ & $18.2(4.6-185)$ \\
\hline $\mathrm{Se}$ & $0.508(0.028-2.09)$ & $0.182(0.048-1.490)$ & $0.697(0.052-2.890)$ & $0.072(0.026-0.309)$ & $0.191(0.027-1.95)$ \\
\hline Sn & $0.185(0.058-4.85)$ & $0.143(0.033-1.490)$ & $0.108(0.060-8.37)$ & $0.142(0.065-2.58)$ & $0.123(0.068-1.01)$ \\
\hline $\mathrm{Tl}$ & $0.141(0.016-1.36)$ & $0.070(0.007-1.58)$ & $0.019(0.005-2.02)$ & $0.095(0.015-14.3)$ & $0.025(0.006-1.39)$ \\
\hline $\mathrm{U}$ & $0.174(0.005-3.440)$ & $0.049(0.007-0.745)$ & $0.023(0.002-0.326)$ & $0.045(0.004-0.201)$ & $0.021(0.001-1.350)$ \\
\hline $\mathrm{V}$ & $1.635(0.069-57.1)$ & $0.496(0.097-3.3)$ & $0.428(0.087-5.6)$ & $0.611(0.07-3.2)$ & $0.273(0.047-32.1)$ \\
\hline $\mathrm{Zn}$ & $81.1(3.3-9730)$ & $56.1(12.0-968)$ & $30.1(15.7-169)$ & $57.5(14.0-407)$ & $27.5(9.6-152)$ \\
\hline
\end{tabular}

trients. Nickel is an element that occurs in the environment only at very low levels and is essential in small doses, but it can be dangerous when the maximum tolerable amounts are exceeded. Its concentration is generally low in our samples, ranging between $0.677 \mathrm{mg} \cdot \mathrm{kg}^{-1}$ of Avellino to $1.440 \mathrm{mg} \cdot \mathrm{kg}^{-1}$ of Caserta, with some maximum values of around $18 \mathrm{mg} \cdot \mathrm{kg}^{-1}$ for the Caserta and Salerno areas. Snails bio-accumulate highest levels of the other three elements: $\mathrm{Cu}$ value range from $18.2 \mathrm{mg} \cdot \mathrm{kg}^{-1}$ of the Salerno area to $87.8 \mathrm{mg} \cdot \mathrm{kg}^{-1}$ of the area of Napoli; $\mathrm{Zn}$ value range from $27.5 \mathrm{mg} \cdot \mathrm{kg}^{-1}$ of the Salerno area to $81.1 \mathrm{mg} \cdot \mathrm{kg}^{-1}$ of the area of Caserta; Mn value range from 14.4 of the Napoli area to $62.5 \mathrm{mg} \cdot \mathrm{kg}^{-1}$ of the area of Caserta. These values are in line with what reported by Albanese [19] in their study of sediment samples from Campania region. Thanks to the direct contact with soil, metal concentration in snails reflects the distribution of these data on soil. Their geochemical maps showed that the baseline values for $\mathrm{Cu}$ ranged from $5 \mathrm{mg} \cdot \mathrm{kg}^{-1}$ to $157 \mathrm{mg} \cdot \mathrm{kg}^{-1}$, with high values for the areas south of Mt. Vesuvius (Napoli), the Cilento area (Salerno) and the territorial belt from the northern side of Mt. Taburno (Benevento) to the southern part of the city of Avellino. All these territories are rich in flourishing vineyard crops: our results in snails are in line with the assumption that soil copper values are certainly influenced by the $\mathrm{Cu}$-sulfate intensely used in viticulture.

Also for Zn. baseline value lower than $82 \mathrm{mg} \cdot \mathrm{kg}^{-1}$ can be assumed to represent the natural background for the whole Campania region, especially for those areas where siliciclastic and alluvial deposits outcrop. In fact, zinc occurs natu- 
rally in soil (about $70 \mathrm{mg} \cdot \mathrm{kg}^{-1}$ in crustal rocks) [20] and is abundant in sedimentary materials and clayey soils [21], such as alluvial and alluvial-colluvial soils. Even though our values are under the media for the territory of Campania, it is the most abundant element in snails (total median value of $44.5 \mathrm{mg} \cdot \mathrm{kg}^{-1}$ ), therefore the fact that $\mathrm{Zn}$ concentrations are rising unnaturally due to anthropogenic additions is indisputable. Most $\mathrm{Zn}$ could increase during industrial activities, such as mining, coal, and waste combustion and steel processing. Industrial sources or toxic waste sites may cause the concentrations of $\mathrm{Zn}$ in drinking water to reach levels that can cause health problems.

Selenium and Cobalt concentrations are also lower in compare to the baseline value found for these elements in the soil, with the difference of a Se prevalence in snail samples respect to Co.

Between the most common heavy metals generally found at contaminated sites there are also the not essential elements $\mathrm{Pb}, \mathrm{Hg}, \mathrm{Cd}, \mathrm{As}$ and $\mathrm{Cr}$ [22]. Lead, one of the most important decay products of $U$ and $T h$, is well known to be toxic and its effects have been more extensively reviewed than the effects of other trace metals. Lead can cause serious injury to the brain, nervous system, red blood cells and kidneys [23]. Exposure to lead can result in a wide range of biological effects depending on the level and duration of exposure. The most serious source of exposure to lead is through direct ingestion (eating) or inhalation of contaminated soil or dust. Our results are lower than those reported for the soil samples of Campania region (from 5 to $51 \mathrm{mg} \cdot \mathrm{kg}^{-1}$ ).

From the same periodic table group of $\mathrm{Cd}$ and $\mathrm{Zn}$, mercury is a naturally occurring element found in air, water and soil, whose exposure-even small amounts-may cause serious health problems. Fortunately, it is the metal less present in our samples (from 0.009 to $0.012 \mathrm{mg} \cdot \mathrm{kg}^{-1}$ ) for each site of the region.

Together with $\mathrm{Pb}$ and $\mathrm{Hg}$, cadmium is one of the big three toxic heavy metal and is not known for any essential biological function. Its presence into the environment is generally related to human activities and, in spite of its low soil content, $\mathrm{Cd}$ is toxic at much lower concentrations than the other elements. Because it is directly below $\mathrm{Zn}$ in the periodic table, it has a chemical similarity to that of $\mathrm{Zn}$, an essential micronutrient for plants and animals. This may account in part for Cd toxicity because of the $\mathrm{Zn}$ substitution by $\mathrm{Cd}$ may cause the malfunctioning of metabolic processes [24]. The mean Cd values range from 0.496 $\mathrm{mg} \cdot \mathrm{kg}^{-1}$ of the Benevento snail group to $0.923 \mathrm{mg} \cdot \mathrm{kg}^{-1}$ of those from Avellino (Figure 2).

Most of the regional territory has moderate $\mathrm{Cd}$ baseline values below 0.43 $\mathrm{mg} \cdot \mathrm{kg}^{-1}$ and highest value can be related to the natural background of regional volcanoclastic deposits, as previously reported by Albanese [19]. Snails are able to sequestrate and detoxify $\mathrm{Cd}$ via complexation to specific cadmium metallothioneins and hence can accumulate $\mathrm{Cd}$ far above environmental concentrations without showing any metabolic disorders [25]. Cd results in snails (mean value $0.710 \mathrm{mg} \cdot \mathrm{kg}^{-1}$ ) appear high only when compared with data from other countries, such as France [8], where the presence of this element is around $0.55 \mathrm{mg} \cdot \mathrm{kg}^{-1}$ 


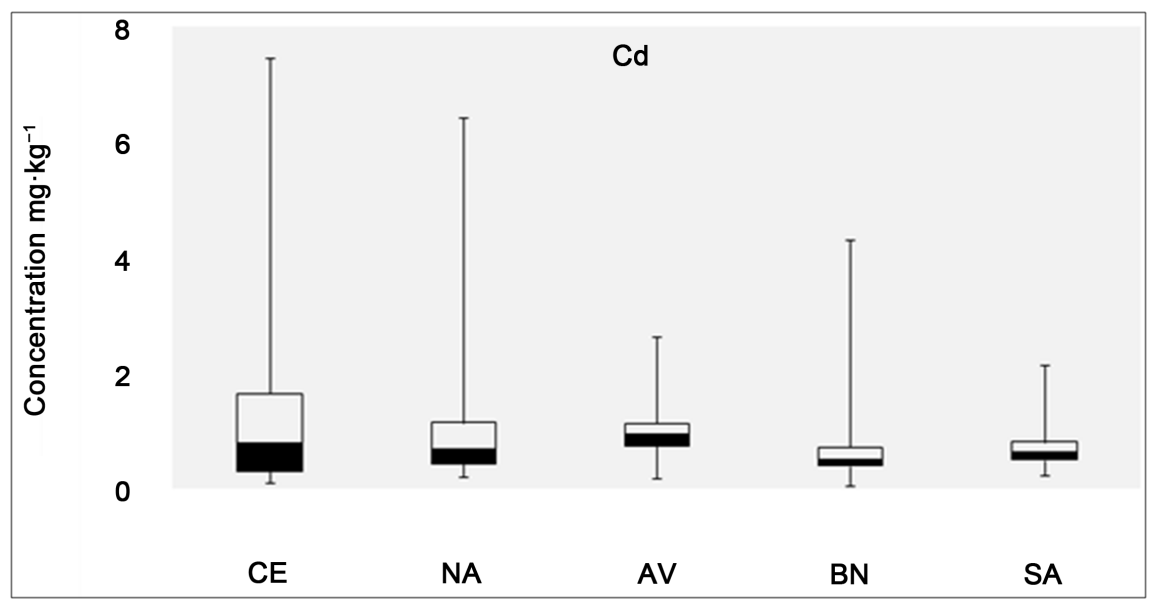

Figure 2. Box and whiskers plot for Cd concentrations in the five areas of Campania Region with the exception of the three highest values of Caserta $(\mathrm{CE})(10.5,15.7,19$ $\left.\mathrm{mg} \cdot \mathrm{kg}^{-1}\right)$.

also taking into consideration snails reared in some contaminated areas. This could be probably due to the application of agricultural inputs such as fertilizers, pesticides, the disposal of industrial wastes or the deposition of atmospheric contaminants that increases the total concentration of $\mathrm{Cd}$ in soils and the bioavailability in plants. On the contrary, the other metal concentrations are in general lower than the results founded in the viscera of snails from France where mean values of $\mathrm{Zn}, \mathrm{Cu}$ and $\mathrm{Pb}$ are about $473.8 \mathrm{mg} \cdot \mathrm{kg}^{-1}, 138.8 \mathrm{mg} \cdot \mathrm{kg}^{-1}$ and 36.1 $\mathrm{mg} \cdot \mathrm{kg}^{-1}$ respectively.

The metalloid arsenic occurs in a wide variety of minerals, highly correlated to the pyroclastic deposits that generally cover carbonate rocks outcropping mostly in the North West and southeast sector of the region [19]. It is, in fact, more abundant in the Caserta area that is in the North West side of region (median value of $0.358 \mathrm{mg} \cdot \mathrm{kg}^{-1}$ with a maximum of $7.9 \mathrm{mg} \cdot \mathrm{kg}^{-1}$ ).

$\mathrm{Cr}$ concentration, that is generally due to anthropogenic activities, ranged between $0.900 \mathrm{mg} \cdot \mathrm{kg}^{-1}$ of Caserta to $0.300 \mathrm{mg} \cdot \mathrm{kg}^{-1}$ of Avellino and Salerno, which are confirmed as the less contaminated areas.

More toxic to humans than mercury, cadmium, lead, copper or zinc is thallium ( $\mathrm{Tl})$, a rare but widely dispersed element. All forms of thallium are soluble enough to be toxic to living organisms [26]. Human contamination can occur from oral ingestion as well as through the skins and lungs, especially if exposed to thallium-contaminated dust from lead and zinc smelting plants, pyrite burners, and similar processing sites [27]. The median content is low $\left(0.070 \mathrm{mg} \cdot \mathrm{kg}^{-1}\right)$ in all the investigated areas, with only a maximum outlier value of $14.3 \mathrm{mg} \cdot \mathrm{kg}^{-1}$ in some snails collected from the territory of Benevento.

The amounts of the only actinide element, uranium, are instead comparable in all the regional territory, ranging from $0.021 \mathrm{mg} \cdot \mathrm{kg}^{-1}$ of Salerno to 0.174 $\mathrm{mg} \cdot \mathrm{kg}^{-1}$ of Caserta.

For the other elements ( $\mathrm{Sb}, \mathrm{Sn}$ and $\mathrm{V}$ ) is still observed the same trend of the others, with a prevalent presence in the Caserta area, particularly for Vanadium 
that is more than two time abundant respect to Benevento (median value of $1.635 \mathrm{mg} \cdot \mathrm{kg}^{-1}$ Caserta-0.611 $\mathrm{mg} \cdot \mathrm{kg}^{-1}$ Benevento).

Statistical analysis between the trace elements assessed through the determination of Pearson correlation coefficients.

Table 2 shows the correlation matrix of the selected elements. It shows the linear relationship between two sets of data. The closer the value gets to zero, the greater the variation the data points are around the line of best fit. The correlation coefficient between most elements was higher than 0.9 , which indicates a strong linear correlation at the 0.01 significance level and a common origin of these metals. Between the three more abundant elements ( $\mathrm{Zn}, \mathrm{Mn}$ and $\mathrm{Cu}$ ) a positive correlations is exhibited only between $\mathrm{Zn}-\mathrm{Mn}$, explaining that they naturally occur at abundant levels and are thus barely affected by human activities. The lack of significant linear correlation between $\mathrm{Cd}, \mathrm{Cu}$, Se and the other elements suggests that their sources were quite different from those of the others.

Multivariate analysis was assessed between the five sites through the Principal Component analysis (PCA) in order to identify metals having similar distribution patterns. The significant principal components (PCs), linear combinations of the observed variables, with VARIMAX normalized rotation,were selected accounting to the Kaiser criterion [28]: only variables with eigenvalues $>1$ were retained for further analysis (Table S1 in Supporting information).

Table 3 shows the factor loadings of the trace elements from the PCA.

Table 2. Pearson's correlation matrix of the selected trace elements in snails from Campania region.

\begin{tabular}{|c|c|c|c|c|c|c|c|c|c|c|c|c|c|c|c|c|}
\hline Metal & $\mathrm{Sb}$ & As & $\mathrm{Cd}$ & Co & $\mathrm{Cr}$ & $\mathrm{Mn}$ & $\mathrm{Hg}$ & $\mathrm{Ni}$ & $\mathrm{Pb}$ & $\mathrm{Cu}$ & $\mathrm{Se}$ & Sn & $\mathrm{Tl}$ & $\mathrm{U}$ & V & $\mathrm{Zn}$ \\
\hline $\mathrm{Sb}$ & 1 & & & & & & & & & & & & & & & \\
\hline As & 0.931 & 1 & & & & & & & & & & & & & & \\
\hline $\mathrm{Cd}$ & -0.032 & 0.180 & 1 & & & & & & & & & & & & & \\
\hline Co & 0.761 & 0.923 & 0.118 & 1 & & & & & & & & & & & & \\
\hline $\mathrm{Cr}$ & 0.937 & 0.980 & 0.064 & 0.929 & 1 & & & & & & & & & & & \\
\hline $\mathrm{Mn}$ & 0.470 & 0.671 & -0.016 & 0.896 & 0.737 & 1 & & & & & & & & & & \\
\hline $\mathrm{Hg}$ & 0.861 & 0.659 & -0.003 & 0.361 & 0.677 & 0.048 & 1 & & & & & & & & & \\
\hline $\mathrm{Ni}$ & 0.886 & 0.972 & 0.228 & 0.876 & 0.909 & 0.571 & 0.592 & 1 & & & & & & & & \\
\hline $\mathrm{Pb}$ & 0.906 & 0.997 & 0.182 & 0.946 & 0.976 & 0.712 & 0.603 & 0.973 & 1 & & & & & & & \\
\hline $\mathrm{Cu}$ & 0.428 & 0.106 & -0.183 & -0.209 & 0.164 & -0.398 & 0.815 & 0.020 & 0.035 & 1 & & & & & & \\
\hline $\mathrm{Se}$ & -0.018 & 0.263 & 0.960 & 0.299 & 0.167 & 0.237 & -0.114 & 0.290 & 0.282 & -0.377 & 1 & & & & & \\
\hline Sn & 0.976 & 0.938 & -0.147 & 0.844 & 0.963 & 0.617 & 0.750 & 0.883 & 0.926 & 0.288 & -0.077 & 1 & & & & \\
\hline $\mathrm{Tl}$ & 0.906 & 0.871 & -0.230 & 0.843 & 0.946 & 0.725 & 0.686 & 0.759 & 0.863 & 0.279 & -0.119 & 0.961 & 1 & & & \\
\hline $\mathrm{U}$ & 0.923 & 0.999 & 0.173 & 0.936 & 0.984 & 0.700 & 0.641 & 0.966 & 0.998 & 0.086 & 0.266 & 0.938 & 0.880 & 1 & & \\
\hline V & 0.880 & 0.985 & 0.194 & 0.965 & 0.984 & 0.778 & 0.575 & 0.933 & 0.991 & 0.019 & 0.315 & 0.911 & 0.883 & 0.991 & 1 & \\
\hline $\mathrm{Zn}$ & 0.939 & 0.878 & -0.136 & 0.794 & 0.947 & 0.637 & 0.791 & 0.760 & 0.859 & 0.408 & -0.064 & 0.956 & 0.984 & 0.882 & 0.878 & 1 \\
\hline
\end{tabular}

High correlation: 0.5 to 1.0 or -0.5 to 1.0 . Medium correlation: 0.3 to 0.5 or -0.3 to 0.5 . Low correlation: 0.1 to 0.3 or -0.1 to -0.3 . 
Table 3. The rotated component matrix of elements in snails from Campania Region (PCA factor loadings greater than 0.32 are shown in bold).

\begin{tabular}{|c|c|c|c|}
\hline & $\mathrm{F} 1$ & F2 & F3 \\
\hline $\mathrm{Sb}$ & 0.283 & -0.156 & 0.112 \\
\hline As & 0.295 & 0.062 & 0.054 \\
\hline $\mathrm{Cd}$ & 0.020 & 0.433 & 0.539 \\
\hline Co & 0.275 & 0.183 & -0.189 \\
\hline $\mathrm{Cr}$ & 0.298 & 0.006 & -0.017 \\
\hline $\mathrm{Mn}$ & 0.211 & 0.225 & -0.409 \\
\hline $\mathrm{Hg}$ & 0.207 & -0.321 & 0.380 \\
\hline $\mathrm{Ni}$ & 0.277 & 0.100 & 0.081 \\
\hline $\mathrm{Pb}$ & 0.293 & 0.093 & 0.014 \\
\hline $\mathrm{Cu}$ & 0.052 & -0.483 & 0.420 \\
\hline $\mathrm{Se}$ & 0.048 & 0.514 & 0.367 \\
\hline Sn & 0.289 & -0.131 & -0.057 \\
\hline $\mathrm{Tl}$ & 0.280 & -0.143 & -0.155 \\
\hline $\mathrm{U}$ & 0.295 & 0.070 & 0.033 \\
\hline $\mathrm{V}$ & 0.293 & 0.112 & -0.010 \\
\hline $\mathrm{Zn}$ & 0.280 & -0.165 & -0.022 \\
\hline
\end{tabular}

The first two factors allow us to represent $87.52 \%$ of the initial variability of the data. In the interpretation of PCA patterns, factor loadings between 0.71 and 0.32 are typically considered medium. While those less than 0.32 are regarded as poor [29]. The PCA loadings for the first two rotated components are plotted in Figure 3.

The Biplot represent the observations and variables simultaneously in the space and visually illustrates the associations among these elements in the five sites of Campania Region. Samples from CE area are all grouped in the positive side of $\mathrm{PC} 1$, and mainly consist of variable $\mathrm{Mn}, \mathrm{Co}, \mathrm{Ni}, \mathrm{V}, \mathrm{As}, \mathrm{Cr}$ (positive side of PC2), $\mathrm{Zn}, \mathrm{Sn}, \mathrm{Sb}$ and $\mathrm{Tl}$ (negative side of PC2), which presents the highest concentrations in these samples. Highest concentration of $\mathrm{Cd}$ and Se are characteristic of the AV area. Samples grouped in the negative side of the two PCs, from SA. BN and NA have the lowest content of elements, revealing their reduced influence on the reference sample group, except for $\mathrm{Cu}$ and $\mathrm{Hg}$ that represents the only two elements more abundant in NA area. Samples from Salerno and Avellino, which are the more distant from all the variables, confirm that contamination in these two areas is at soil's background level.

\section{Conclusions}

Metal concentrations in the different groups showed that snails accumulate certain metals ( $\mathrm{Zn}, \mathrm{Pb}$ and $\mathrm{Cd}$ ) and that this bioaccumulation occurs more in the Caserta area. It represents a potentially polluted area where the anthropogenic 


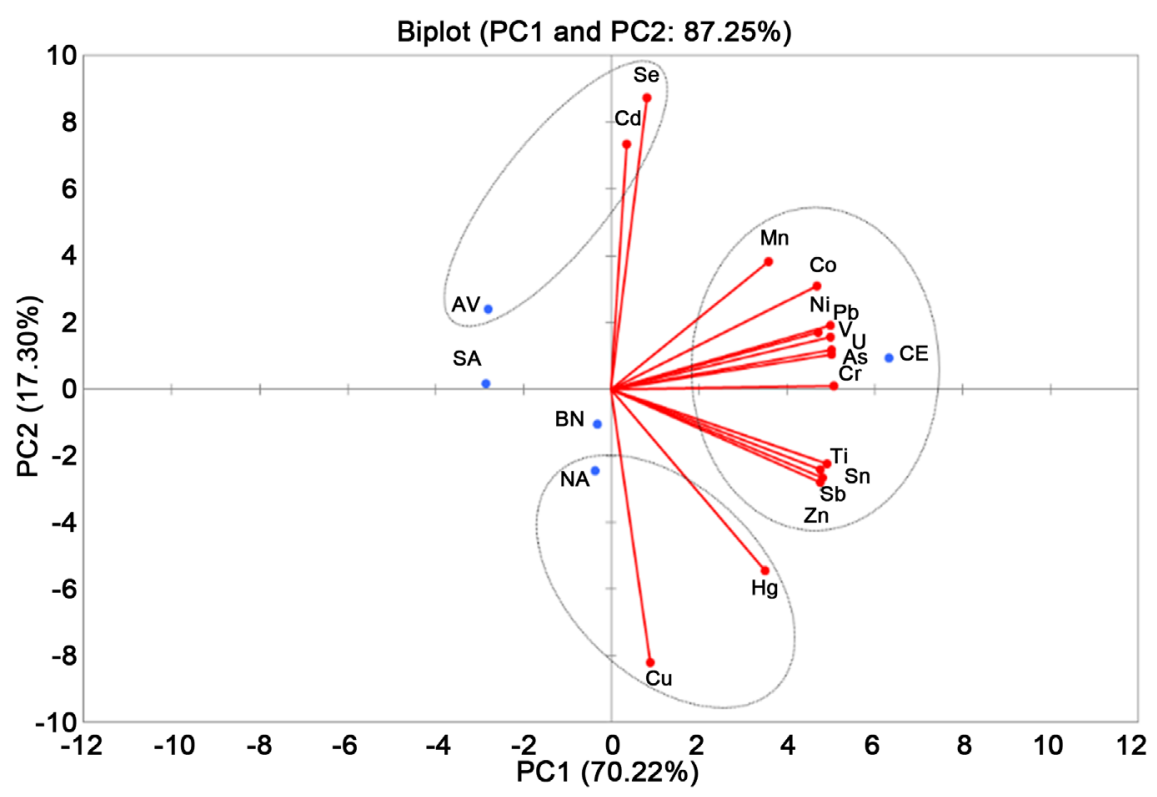

Figure 3. Biplot of PC1 and PC2 for trace element data.

influence is clearly evident, due not only to the wide extent of local industrial and agricultural activities, but also to the illegal spillage of toxic waste and of uncontrolled fire [30]. These phenomena are in fact the characteristic of the lands between the territory of Caserta and Napoli, which must be therefore the object of intense environmental controls.

Used as sentinels, snails are representative primary consumers in the terrestrial ecosystem, and they are useful key indicator species to evaluate the environmental impact of chemical on our lands.

Even though the sample collection may be done seasonally to avoid the climatic factors which affect on metals transfer, our work could be considered a preliminary monitoring program useful to obtain information on the real trace element contamination rates of the lands of our region.

\section{Acknowledgements}

We would like to thank Andrea Pierri for the map of Campania region. This study was supported by the "Regione Campania" as part of the project "Campania Trasparente", and of the "Ricerca Corrente IZSME 10/14 RC".

\section{References}

[1] Esposito, M., Serpe, F.P., Neola, B., Sansone, D., Fiorito, F. and Cerino, P. (2016) Use of Snails (Helix aspersa) as Sentinels to Evaluate Environmental Contamination by Polycyclic Aromatic Hydrocarbons and Trace Element. 70 th Convegno SISVET ts Conference, Palermo, Italy.

[2] Wuana, R.A. and Okieimen, F.E. (2011) Heavy Metals in Contaminated Soils: A Review of Sources. Chemistry. Risks and Best Available Strategies for Remediation. ISRN Ecology, 2011, Article ID: 402647.

[3] McLaughlin, M.J., Zarcinas, B.A., Stevens, D.P. and Cook, N. (2000) Soil Testing for Heavy Metals. Communications in Soil Science and Plant Analysis, 31, 1661-1700. 
https://doi.org/10.1080/00103620009370531

[4] McLaughlin, M.J., Hamon, R.E., McLaren, R.G., Speir, T.W. and Rogers, S.L. (2000) Review: A Bioavailability-Based Rationale for Controlling Metal and Metalloid Contamination of Agricultural Land in Australia and New Zealand. Australian Journal of Soil Research, 38, 1037-1086. https://doi.org/10.1071/SR99128

[5] Ling, W., Shen, Q., Gao, Y., Gu, X. and Yang, Z. (2007) Use of Bentonite to Control the Release of Copper from Contaminated Soils. Australian Journal of Soil Research, 45, 618-623. https://doi.org/10.1071/SR07079

[6] Oehlmann, J. and Schulte-Oehlmann, U. (2002) Bioindicators and Biomonitors, Chapter 17 Molluscs as Bioindicators. Eselvier Science B.V.

[7] Ravera, O. (2001) Monitoring of the Aquatic Environment by Species Accumulator of Pollutants: A Review. Journal of Limnology, 60, 63-78.

https://doi.org/10.4081/jlimnol.2001.s1.63

[8] Gomot de Vaufleury, A. and Pihan, F. (2000) Growing Snails Used as Sentinels to Evaluate Terrestrial Environment Contamination by Trace Elements. Chemosphere, 40, 275-284. https://doi.org/10.1016/S0045-6535(99)00246-5

[9] Coughtrey, P.J. and Martin, M.H. (1977) The Uptake of Lead, Zinc, Cadmium, and Copper by the Pulmonate Mollusk, Helix aspersa Müller, and Its Relevance to the Monitoring of Heavy Metal Contamination of the Environment. Oecologia, 27, 6574. https://doi.org/10.1007/BF00345685

[10] Regoli, F., Gorbi, S., Fattorini, D., Tedesco, S., Notti, A., Machella, N., Bocchetti, R. and Benedetti, M. (2006) Use of the Land Snail Helix aspersa as Sentinel Organism for Monitoring Ecotoxicologic Effects of Urban Pollution: An Integrated Approach. Environmental Health Perspectives, 114, 63-69. https://doi.org/10.1289/ehp.8397

[11] Menta, C. and Parisi, V. (2001) Metal Concentrations in Helix pomatia. Helix aspersa and Arionrufus. A Comparative Study. Environmental Pollution, 115, 205208. https://doi.org/10.1016/S0269-7491(01)00110-5

[12] Scheifler, R., Gomot, A., de Vauflenry, A. and Badot, P.M. (2002) Transfer of Cadmium from Plant Leaves and Vegetable Flour to the Snail Helix aspersa: Bioaccumulation and Effects. Ecotoxicology and Environmental Safety, 53, 148-153. https://doi.org/10.1006/eesa.2002.2216

[13] Gimbert, F., de Vaufleury, A., Douay, F., Coeurdassier, M., Scheifler, R. and Badot, P.M. (2006) Modellingchronicexposure to Contaminated Soil: A Toxicokinetic Approach with the Terrestrial Snail Helix aspersa. Environment International, 32, 866875. https://doi.org/10.1016/j.envint.2006.05.006

[14] Abdel-Halim, K.Y., Abo El-Saad, A.M., Talha, M.M., Hussein, A.A. and Bakry, N.M. (2013) Oxidative Stress on Land Snail Helix aspersa as a Sentinel Organism for Ecotoxicological Effects of Urban Pollution with Heavy Metals. Chemosphere, 93, 1131-1138. https://doi.org/10.1016/j.chemosphere.2013.06.042

[15] Larba, R. and Soltani, N. (2014) Use of the Land Snail Helix aspersa for Monitoring Heavy Metal Soil Contamination in Northeast Algeria. Environmental Monitoring and Assessment, 186, 4987-4995. https://doi.org/10.1007/s10661-014-3753-2

[16] Corda, A., Mara, L., Virgilio, S., Pisanu, M., Chessa, G., Parisi, A. and Cogoni, M.P. (2014) Microbiological and Chemical Evaluation of Helix spp. Snails from Local and Non-EU Markets Utilised as Food in Sardinia. Italian Journal of Food Safety, 3, 1732. https://doi.org/10.4081/ijfs.2014.1732

[17] Cicero, A., Giangrosso, G., Cammilleri, G., Macaluso, A., Currò, V., Galuppo, L., Vargetto, D., Vicari, D. and Ferrantelli, V. (2015) Microbiological and Chemical Analysis of Land Snails Commercialised in Sicily. Journal of Food Safety, 4, 4196. https://doi.org/10.4081/ijfs.2015.4196 
[18] EPA (2015) Method 6020 B.

https://www.epa.gov/sites/production/files/2015-12/documents/6020b.pdf

[19] Albanese, S., De Vivo, B., Lima, A. and Cicchella, D. (2007) Geochemical Background and Baseline Values of Toxic Elements in Stream Sediments of Campania Region. Italy Journal of Geochemical Exploration, 93, 21-34. https://doi.org/10.1016/j.gexplo.2006.07.006

[20] Davies, B.E. and Jones, L.H.P. (1988) Micronutrients and Toxic Elements. In: Wild, A., Ed., Russell s Soil Conditions and Plant Growth, 11th Edition, John Wiley \& Sons, New York, 781-814.

[21] Kabata-Pendias, A. and Pendias, H. (2001) Trace Elements in Soils. 3rd Edition, CRC Press, Boca Raton, 413.

[22] USEPA (1996) Report: Recent Developments for in Situ Treatment of Metals Contaminated Soils. US Environmental Protection Agency, Office of Solid Waste and Emergency Response.

[23] Baldwin, D.R. and Marshall, W.J. (1999) Heavy Metal Poisoning and Its Laboratory Investigation. Annals of Clinical Biochemistry, 36, 267-300.

https://doi.org/10.1177/000456329903600301

[24] Campbell, P.G.C. (2006) Cadmium-A Priority Pollutant. Environmental Chemistry, 3, 387-388. https://doi.org/10.1071/EN06075

[25] Nica, D.V., Filimon, M.N., Bordean, D.M., Harmanescu, M., Draghici, G.A., Dragan, S. and Gergen I.I. (2015) Impact of Soil Cadmium on Land Snails: A Two-Stage Exposure Approach under Semi-Field Conditions Using Bioaccumulative and Conchological End-Points of Exposure. PLOS ONE, 10, e0116397. https://doi.org/10.1371/journal.pone.0116397

[26] Peter, A.L. and Viraraghavan, T. (2005) Thallium: A Review of Public Health and Environmental Concerns. Environment International, 31, 493-501. https://doi.org/10.1016/j.envint.2004.09.003

[27] Kochare, T. and Tamir, B. (2015) Assessment of Dairy Feeds for Heavy Metals. American Scientific Research Journal for Engineering. Technology and Sciences, 11, 20-31.

[28] Kaiser, H.F. (1960) The Application of Electronic Computers to Factor Analysis. Educational and Psychological Measurement, 20, 141-151. https://doi.org/10.1177/001316446002000116

[29] Hu, Y., Liu, X., Bai, J., Shih, K., Zeng, E.Y. and Cheng, H. (2013) Assessing Heavy Metal Pollution in the Surface Soils of a Region That Had Undergone Three Decades of Intense Industrialization and Urbanization. Environmental Science and Pollution Research, 20, 6150-6159. https://doi.org/10.1007/s11356-013-1668-Z

[30] Triassi, M., Alfano, R., Illario, M., Nardone, A., Caporale, O. and Montuori, P. (2015) Environmental Pollution from Illegal Waste Disposal and Health Effects: A Review on the "Triangle of Death". International Journal of Environmental Research and Public Health, 12, 1216-1236. https://doi.org/10.3390/ijerph120201216 
Submit or recommend next manuscript to OALib Journal and we will provide best service for you:

- Publication frequency: Monthly

- 9 subject areas of science, technology and medicine

- Fair and rigorous peer-review system

- Fast publication process

- Article promotion in various social networking sites (LinkedIn, Facebook, Twitter, etc.)

- Maximum dissemination of your research work

Submit Your Paper Online: Click Here to Submit

Or Contact service@oalib.com 